\title{
INSECTIVORE ART IN TRANSIT
}

CAROLYN BRAAKSMA $・$ and $・$ ChrIS LANGE $・$ Charlotte $・$ North Carolina $・$ USA $・$ braaksma.design@ gmail.com・clange@charlottenc.gov

Art reflects nature in a monumental way on the new section of the LYNX Blue Line in Charlotte, North Carolina. Forty-five concrete retaining walls that cumulatively make up 4 miles $(6.4 \mathrm{~km})$ of the 9.6-mile $(15.5-\mathrm{km})$ light rail extension project display a wide variety of carnivorous plants and orchids that are indigenous to the Carolinas. Denver artist Carolyn Braaksma was commissioned by [Charlotte Area Transit System] CATS Art in Transit to create the patterns for a variety of wall types and sizes, including enhancing four rail bridges connecting to the art walls.
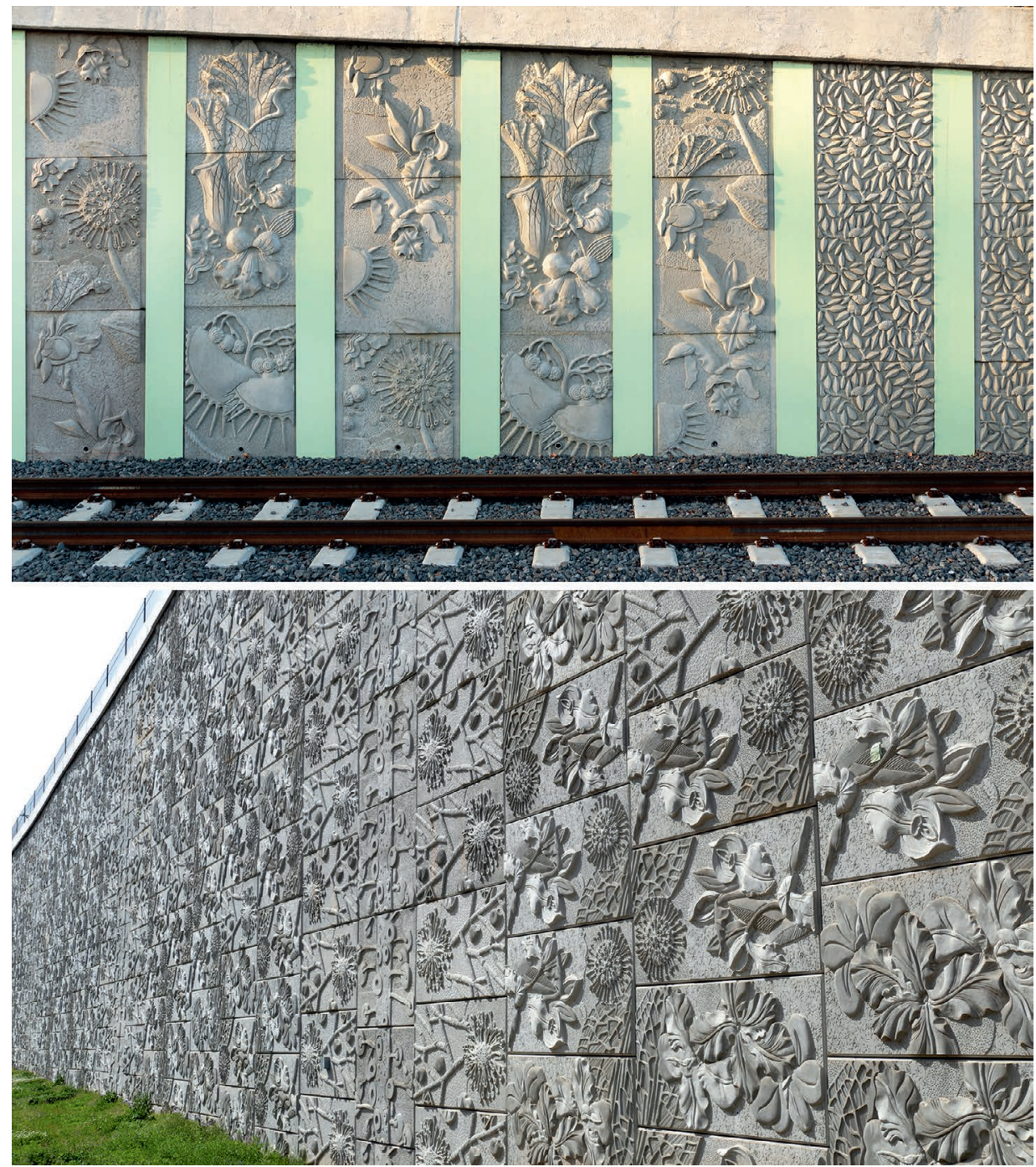


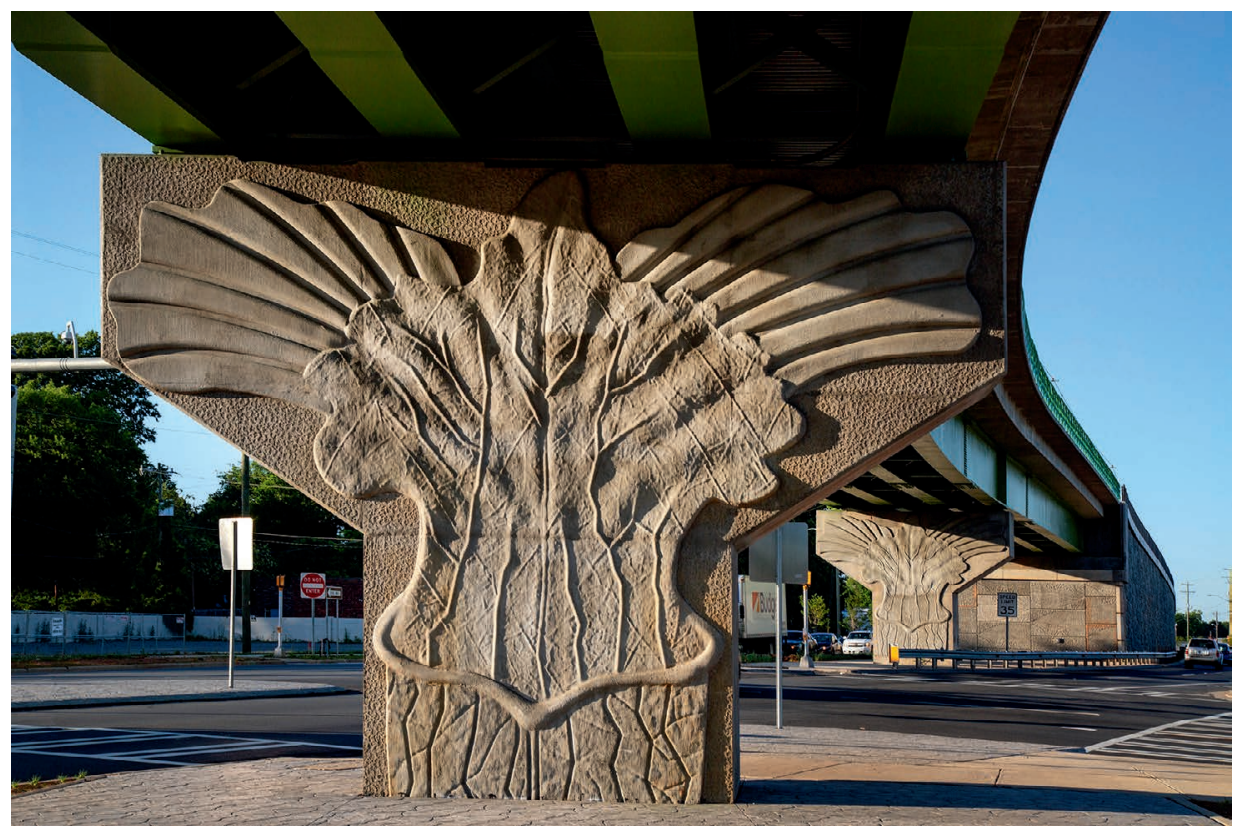

In the spring of 2013, Braaksma spent three months at the McColl Center for Visual Art in a CATS-sponsored residency to provide her access to the project team and the Charlotte community during the Blue Line Extension design phase. Early in the residency, she visited UNC Charlotte's Botanical Gardens, where she learned that the Carolinas were home to many orchids and indigenous insectivores including Pitcher Plant varieties (Sarracenia), Venus flytrap (Dionaea), Sundews (Drosera) and Bladderworts (Utricularia). These plants became the inspiration for the wall patterns. Over the course of her residency, she shared her art process with the public and met with area students as she created her large-scale drawings that would be translated into concrete relief on the project walls. She carved her first full-sized prototype of Calico Kudzu, mapped out over 300,000 $\mathrm{ft}^{2}\left(27,871 \mathrm{~m}^{2}\right)$ of wall designs, and designed her green leaf railings for the four bridges. The bridge girders, colored green as specified by the artist, visually tie her railings to the girders under each bridge span. Two of the bridges are supported by her Pitcher Plant Bridge Piers; each pier measures $25 \mathrm{ft}(7.6 \mathrm{~m})$ across and $18 \mathrm{ft}(5.5 \mathrm{~m})$ high.

Braaksma's wall layouts and naming of the walls were also influenced by textile patterns. Her panel walls consist of a module with seven or four repeated columns divided by a Sundew or Pitcher Plant pilaster. By rotating her panels within each seven or four columns, she increased the variations throughout the many miles of art. In a single $4.5 \times 5 \mathrm{ft}(1.4 \times 1.5 \mathrm{~m})$ panel, a tiny recognizable insectivore like the Venus flytrap is depicted in macro proportions. The imagery is based on indigenous North Carolina plant life while the art wall titles capture both her plant and textile references to further intrigue the viewers.

For each of her 17 different designs, Braaksma spent over a year carving her full-scale prototypes, ranging in size from $5 \times 5 \mathrm{ft}(1.5 \times 1.5 \mathrm{~m})$ to $20 \times 20 \mathrm{ft}(6.1 \times 6.1 \mathrm{~m})$. She managed her subcontractor in Denver during the production of the 17 master molds produced from her prototypes. The masters were then provided to CATS contractors to fabricate the form liners for concrete and the subsequent building of the walls, which occurred from 2015 until the line opened in March 2018. 
This is the first time to our knowledge carnivorous plants have been incorporated into retaining wall public art motifs. Part of the motivation was to use local plants as sources of inspiration for the art expressed in the project as is often the notion with Braaksma's designs.

\section{THE ICPS SEED BANK \\ an exclusive member benefit}

The International Carnivorous Plant Society offers its members exclusive access to a variety of carnivorous plant seeds. Seeds are ordered online at the ICPS Store:

\section{http://icps.clubexpress.com}

The Seed Bank cannot exist without seed donations. Information about growing carnivorous plants from seed and donating seeds to the Seed Bank are at the ICPS public web site:

http://www.carnivorousplants.org

If you do not have access to the Internet, please send seed order form requests to:

International Carnivorous Plant Society, Inc.

2121 N. California Blvd., Suite 290

Walnut Creek, CA 94596-7351, USA

JOE GRIFFIN, Seed Bank Manager, joe@carnivorousplants.org

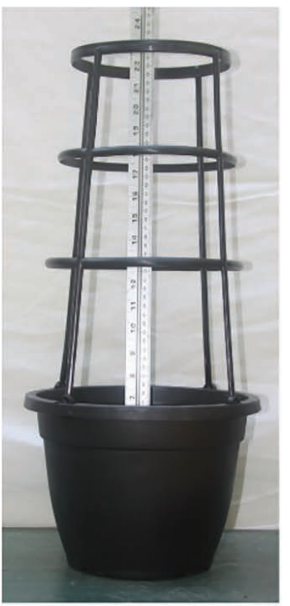

\section{Ferocious Foliage.com}

Custom Tissue Culture Laboratory

Terrific alternative to a hanging basket.

Pots are $10^{\prime \prime}$ in diameter, $71 / 4^{\prime \prime}$ tall with a $\sim 1.75$ gallon capacity.

Terraces are $141 / 2 "$ tall.

info@ferociousfoliage.com

$\$ 5.00$ each $+\mathrm{S} / \mathrm{H}$

Ferocious Foliage

P.O. Box 458

Dahlonega, GA 30533

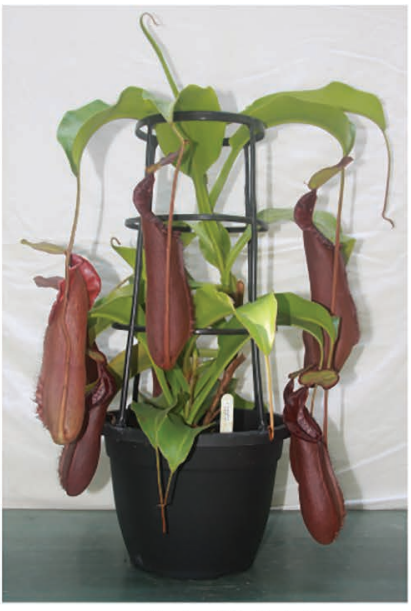

Plant not included 